Article

\title{
Enhancement of the Ionic Conductivity in Electric Field-Assisted Pressureless Sintered BITIVOX Solid Electrolytes
}

\author{
Midilane S. Medina ${ }^{1}$, Sabrina G. M. Carvalho ${ }^{1} \mathbb{D}$, Eliana N. S. Muccillo ${ }^{1}(\mathbb{D})$ and \\ Reginaldo Muccillo 1,2,* \\ 1 Center of Science and Technology of Materials-CCTM, Energy and Nuclear Research Institute-IPEN, \\ S. Paulo, SP 05508-170, Brazil \\ 2 Center of Engineering, Modeling and Applied Social Sciences, Federal University of ABC, Santo André, \\ SP 09210-580, Brazil \\ * Correspondence: muccillo@usp.br; Tel.: +55-11-3133-9203
}

Received: 16 June 2019; Accepted: 25 July 2019; Published: 11 August 2019

\begin{abstract}
Bi}_{4} \mathrm{~V}_{1.8} \mathrm{Ti}_{0.2} \mathrm{O}_{11}$ (BITIVOX) ceramic pellets, prepared with powders obtained by a sol gel technique, were sintered either conventionally at $800^{\circ} \mathrm{C} / 8 \mathrm{~h}$ or by applying an AC electric voltage, limiting the electric current through the pellets. Electric voltages were applied isothermally at $700{ }^{\circ} \mathrm{C}$ and $800{ }^{\circ} \mathrm{C}$ during $5 \mathrm{~min}$ in the green pellet positioned in the sample holder of a dilatometer for monitoring thickness variation. The BITIVOX pellets shrank $13.6 \%$ after applying $200 \mathrm{~V} \mathrm{~cm}^{-1}$ at $800{ }^{\circ} \mathrm{C}$ and $10.4 \%$ heating to $800^{\circ} \mathrm{C}$ for $8 \mathrm{~h}$. Thermal analysis and $\mathrm{X}$-ray diffraction of the powders were performed to evaluate the crystallization temperature and the structural phase, respectively. The electrical behavior of the sintered BITIVOX pellets was analyzed by the impedance spectroscopy technique, showing that the sample flash sintered at $800^{\circ} \mathrm{C} / 5 \mathrm{~min}$ had lower bulk resistivity than the sample conventionally sintered at $800^{\circ} \mathrm{C} / 8 \mathrm{~h}$. The surfaces of the sintered pellets were observed in a scanning electron microscope showing similar grain sizes and pore content in all sintered samples.
\end{abstract}

Keywords: BIMEVOX; solid electrolyte; flash sintering; impedance spectroscopy

\section{Introduction}

Oxide ion ceramic solid electrolytes find uses in many commercial devices, e.g., solid oxide fuel cells (SOFCs), oxygen sensors, and oxygen electrochemical pumps [1-6]. The most important ceramic solid electrolyte is the cubic fully stabilized zirconia $\mathrm{ZrO}_{2}: 8 \mathrm{~mol} \% \mathrm{Y}_{2} \mathrm{O}_{3}$ (8YSZ), which is a component of SOFCs with $0.01 \mathrm{~S} \mathrm{~cm}^{-1}$ electrical conductivity at $800{ }^{\circ} \mathrm{C}$ to ensure high power densities [7]. Since 1982 solid electrolytes with oxide ion conductivity higher than that of $8 \mathrm{YSZ}$ have been proposed: $\mathrm{CeO}_{2}: 20$ mol\% $\mathrm{Gd}_{2} \mathrm{O}_{3}$ (GDC, gadolinia-doped ceria) in 1982 [8], $\mathrm{Bi}_{4} \mathrm{~V}_{2-\mathrm{x}} \mathrm{Me}_{\mathrm{x}} \mathrm{O}_{11}$ (BIMEVOX) in 1990 [9], $\mathrm{CeO}_{2}: 20$ $\mathrm{mol} \% \mathrm{Sm}_{2} \mathrm{O}_{3}$ (SDC, samaria-doped ceria) in 1992 [10], $\mathrm{La}_{0.9} \mathrm{Sr}_{0.1} \mathrm{Ga}_{0.8} \mathrm{Mg}_{0.2} \mathrm{O}_{3-\delta}$ (LSGM, strontium- and magnesium-doped lanthanum gallate) in 1996 [11], and $\mathrm{La}_{2} \mathrm{Mo}_{2} \mathrm{O}_{9}$ (LAMOX, lanthanum molybdenum oxide) in 2000 [12]. A solid electrolyte with ionic conductivity higher than that of 8YSZ would allow for designing SOFCs operating at lower temperatures, thus reducing misfit problems between solid electrolyte and other components in those devices, like anode and cathode.

BIMEVOX solid electrolytes are obtained by partially replacing $\mathrm{V}^{5+}$ with pentavalent or aliovalent ions in the $\mathrm{Bi}_{4} \mathrm{~V}_{2} \mathrm{O}_{11}$ compound. Several BIMEVOX compounds have been synthesized with single or double replacements with several different metallic ions, $\mathrm{Li}^{+}, \mathrm{Cu}^{2+}, \mathrm{Co}^{2+}, \mathrm{Ni}^{2+}, \mathrm{Zn}^{2+}, \mathrm{Fe}^{3+}, \mathrm{Al}^{3+}$, $\mathrm{Ti}^{4+}, \mathrm{Zr}^{4+}, \mathrm{Ge}^{4+}, \mathrm{Sn}^{4+}, \mathrm{Pb}^{4+}, \mathrm{Nb}^{5+}$ [13-32]. The structural phases of $\mathrm{Bi}_{4} \mathrm{~V}_{2} \mathrm{O}_{11}$ are monoclinic (named alpha), orthorhombic from $445^{\circ} \mathrm{C}$ (beta) and tetragonal from $567^{\circ} \mathrm{C}$ (gamma), the gamma phase 
with the highest oxygen ion conductivity [23,32]. The tetragonal gamma phase may be partially or fully stabilized at room temperature by aliovalent replacements for $\mathrm{V}^{5+}$. Therefore, bismuth oxide and doped bismuth oxide systems exhibit a complex set of crystallographic structures and electrical properties, which depend upon temperature, atmosphere, dopant type, and concentration. The best bismuth-based ionic conductor is the $\mathrm{Bi}_{4} \mathrm{~V}_{1.8} \mathrm{Ti}_{0.2} \mathrm{O}_{10.9}$ compound.

Flash sintering (FS) is an electric field-assisted pressureless sintering technique accomplished in short times, from seconds to minutes, in comparison with the time required in conventional sintering (hours). That technique has been widely applied to sinter several electroceramics at temperatures lower than those used in conventional sintering, producing consolidated bodies without considerable grain growth [33-38]. Sintering to near full density with that technique may be achieved by applying moderate electric fields (tens of Volts) with limiting currents ( $\mathrm{mA}$ to few A range) to green ceramic pellets isothermally at temperatures below the conventional temperature for sintering, saving time and energy consumption.

The synthesis by the complex polymerization chemical method of BITIVOX powders and the conformation by electric field-assisted (flash) pressureless sintering at temperatures similar to and lower than those previously conventionally used for sintering $\left(700^{\circ} \mathrm{C}\right.$ and $800{ }^{\circ} \mathrm{C}$ ) are here reported for the first time. Microstructural analysis and impedance spectroscopy measurements show the possibilities of electric field-assisted pressureless sintering BITIVOX ceramic ionic conductors with improved electrical behavior.

\section{Materials and Methods}

Polycrystalline $\mathrm{Bi}_{4} \mathrm{~V}_{1.8} \mathrm{Ti}_{0.2} \mathrm{O}_{11}$ powders were synthesized by the complex polymerization method with bismuth trioxide $\left(\mathrm{Bi}_{2} \mathrm{O}_{3}\right.$, Riedel-de-Haen), vanadium pentoxide $\left(\mathrm{V}_{2} \mathrm{O}_{5}\right.$, Alfa Aesar $\left.99.2 \%\right)$, titanium (IV) isopropoxide [Ti(OCH $\left.\left(\mathrm{CH}_{3}\right)_{2}\right)_{4}$, Sigma Aldrich 99.999\%], citric acid $\left(\mathrm{C}_{6} \mathrm{H}_{8} \mathrm{O}_{7}, \mathrm{CAAL}\right)$ and ethane-1,2-diol $\left(\mathrm{C}_{2} \mathrm{H}_{4}(\mathrm{OH})_{2}\right.$, ethylene glycol, Vetec, Sigma-Aldrich, St. Louis, MI, USA) according to the Schema shown below. To prepare a solution with titanium, stoichiometric amounts of $\mathrm{Bi}_{2} \mathrm{O}_{3}$ were dissolved in nitric acid ( $\mathrm{HNO}_{3}$, Vetec, Sigma-Aldrich, St. Louis, MI, USA), $\mathrm{V}_{2} \mathrm{O}_{5}$ in citric acid, and $\left[\mathrm{Ti}\left(\mathrm{OCH}\left(\mathrm{CH}_{3}\right)_{2}\right)_{4}\right]$ was dropwise dissolved in citric acid. The $\mathrm{TiO}_{2}$ content was evaluated by gravimetric analysis. The citric acid/metal molar ratio was kept at 4:1. The solution was mixed and stirred at $\sim 100{ }^{\circ} \mathrm{C}$ until it turned homogeneous; ammonium hydroxide $\left(\mathrm{NH}_{4} \mathrm{OH}\right.$, Synth) was used to adjust the $\mathrm{pH}$ to 7 . Afterwards, ethylene glycol was added to promote the citrate polymerization, fixing at 60:40 the mass ratio of the citric acid/ethylene glycol. The solution was then kept under magnetic stirring for several hours up to obtaining a gel. The gel was analyzed by simultaneous thermogravimetric (TG) and differential thermal analysis (DTA) from room temperature to $1000{ }^{\circ} \mathrm{C}$ at $10^{\circ} \mathrm{C} \mathrm{min}{ }^{-1}$ rate under flowing synthetic air in a simultaneous thermal analyzer (Netzsch STA 409E, Selb, Germany).

The powder, after calcination at $750{ }^{\circ} \mathrm{C}$ for removing organics, was pressed uniaxially (50 MPa) into $\varphi 5.0 \times 2.5 \mathrm{~mm}$ pellets and isostatically $(200 \mathrm{MPa})$.

$X$-ray diffraction analyses were carried out in the synthesized ceramic powders and in ground powders of sintered BITIVOX pellets in a diffractometer (D8 Advance, Bruker-AXS, Karlsruhe, Germany) in Bragg-Brentano configuration with $\mathrm{Cu}-\mathrm{k}_{\alpha}$ radiation, scintillation detector, in the $25-60^{\circ}$ $2 \theta$ range, $0.05^{\circ}$ step size, $5 \mathrm{~s}$ per step.

For the flash sintering experiments, BITIVOX cylindrical pellets were positioned into the sample holder of a vertical dilatometer (Unitherm 1161, Anter, Pittsburgh, PA, USA). Platinum grids, placed on both parallel surfaces of the sample, were connected with platinum wires to a custom-made power supply operating at 50-60 V, $1.0 \mathrm{~A}, 1.1 \mathrm{kHz}$. The applied voltage and the electric current through the specimen were collected with two Fluke 8050 A multimeters and stored in a computer [39]. The experimental procedure for flash sintering consisted on applying an electric voltage during $5 \mathrm{~min}$ when the temperature of the specimen reached $700^{\circ} \mathrm{C}$ or $800^{\circ} \mathrm{C}$, monitoring voltage and current pulses with the multimeters, and specimen thickness shrinkage $( \pm 1 \mu \mathrm{m})$ with the dilatometer gauge. Typical 
electric field and current profiles are shown in Figure 1, with initial field and current peaks, the voltage decreasing to a value dependent on the electrical resistance of the sample, to keep constant the pre-set current. The inset shows that the incubation time, i.e., the elapsed time to the occurrence of the electric current pulse, is $3.2 \mathrm{~s}$ and the half-width of the electric current pulse is approximately $0.5 \mathrm{~s}$.

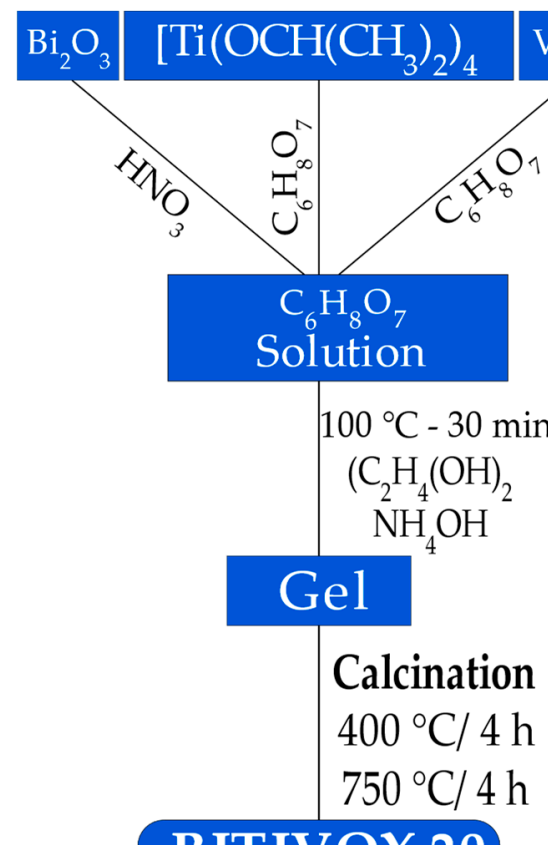

B ITIV OX.20

Schema. Experimental sequence for the synthesis of $\mathrm{Bi}_{4} \mathrm{~V}_{1.8} \mathrm{Ti}_{0.2} \mathrm{O}_{11}$ (BITIVOX) ceramic powders.

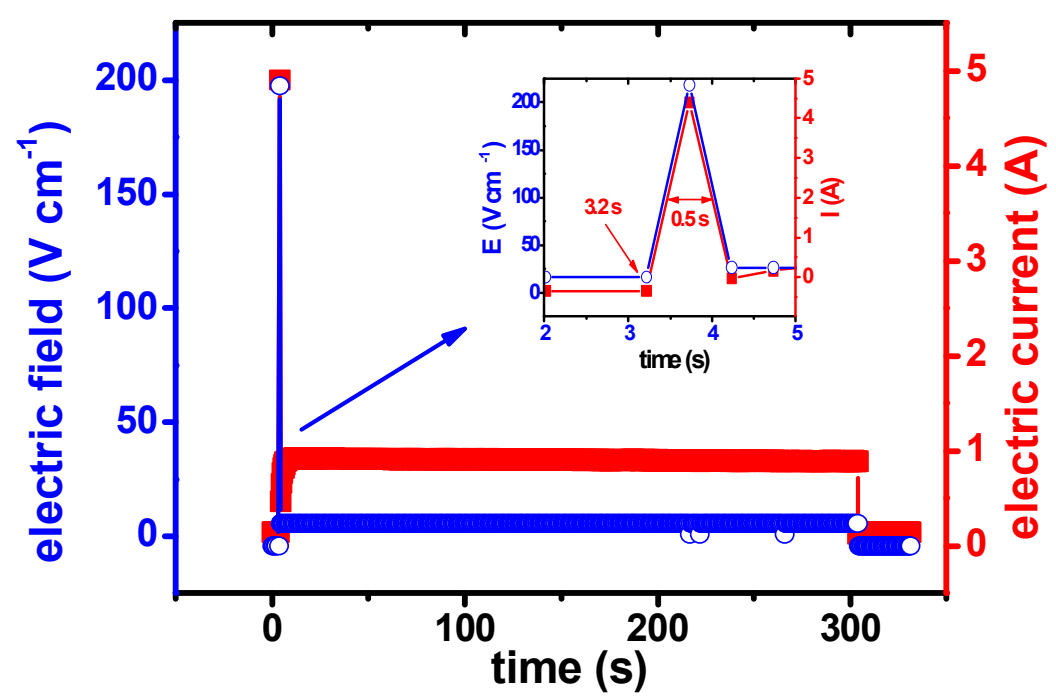

Figure 1. Time evolution of applied electric field and electric current through a BITIVOX pellet during $300 \mathrm{~s}$ at $800^{\circ} \mathrm{C}$. Inset: exploded view of the first $5 \mathrm{~s}$ under the electric field.

The apparent hydrostatic density of the sintered samples was evaluated by the Archimedes method in a Mettler Toledo AG245 analytical balance (Columbus, OH, USA) with a special density determination kit. The evaluated values were in the $76 \%-83 \%$ T.D. range (T.D.: theoretical density, $7.74 \mathrm{~g} \mathrm{~cm}^{-3}$ apud [31]): $5.86 \mathrm{~g} \mathrm{~cm}^{-3}$ (76.2\% T.D.), $6.00 \mathrm{~g} \mathrm{~cm}^{-3}$ (77.5) and $6.43 \mathrm{~g} \mathrm{~cm}^{-3}$ (83.1) for the specimens flash sintered at $700{ }^{\circ} \mathrm{C}$, heat-treated at $800{ }^{\circ} \mathrm{C} / 8 \mathrm{~h}$ and flash sintered at $800{ }^{\circ} \mathrm{C}$, respectively. Denser specimens could be obtained by stripping the external surfaces of the flash sintered specimen. 
Impedance spectroscopy measurements were carried out with a Hewlett Packard $4192 \mathrm{~A}$ impedance analyzer (Yokogawa-Hewlett Packard, Tokyo, Japan) in the $275^{\circ} \mathrm{C}-400^{\circ} \mathrm{C}$ temperature range from $5 \mathrm{~Hz}$ to $13 \mathrm{MHz}, 16$ points per decade, with $200 \mathrm{mV}$ input AC voltage. Three cylindrical samples, with their parallel surfaces covered with silver electrodes, were spring-loaded in a sample chamber with platinum disk electrodes and leads, which was positioned inside a programmable furnace. $\left[-Z^{\prime \prime}(\omega) \times Z^{\prime}(\omega)\right]$ impedance data were collected with a special software [40].

Scanning electron microscopy images were observed with a FEG-SEM microscope (Inspect F50, FEI, Brno, Czech Republic) in the flat surfaces of the sintered pellets.

\section{Results and Discussion}

The thermogravimetric and differential thermal analyses of the synthesized BITIVOX gel are shown in Figure 2. These curves exhibit two main thermal events: a weight loss due to dehydration and evaporation of volatiles, besides the decomposition of free citric acid (added in excess during synthesis) and initial decomposition of the organic matter from room temperature to approximately $200^{\circ} \mathrm{C}$ and an exothermic peak related to organic decomposition from $200^{\circ} \mathrm{C}$ to approximately $480^{\circ} \mathrm{C}$. The inflection of the peak close to $550^{\circ} \mathrm{C}$ points out to the beginning of the crystallization process. Based on these results, calcination at $750{ }^{\circ} \mathrm{C}$ was then carried out for producing the BITIVOX powders.

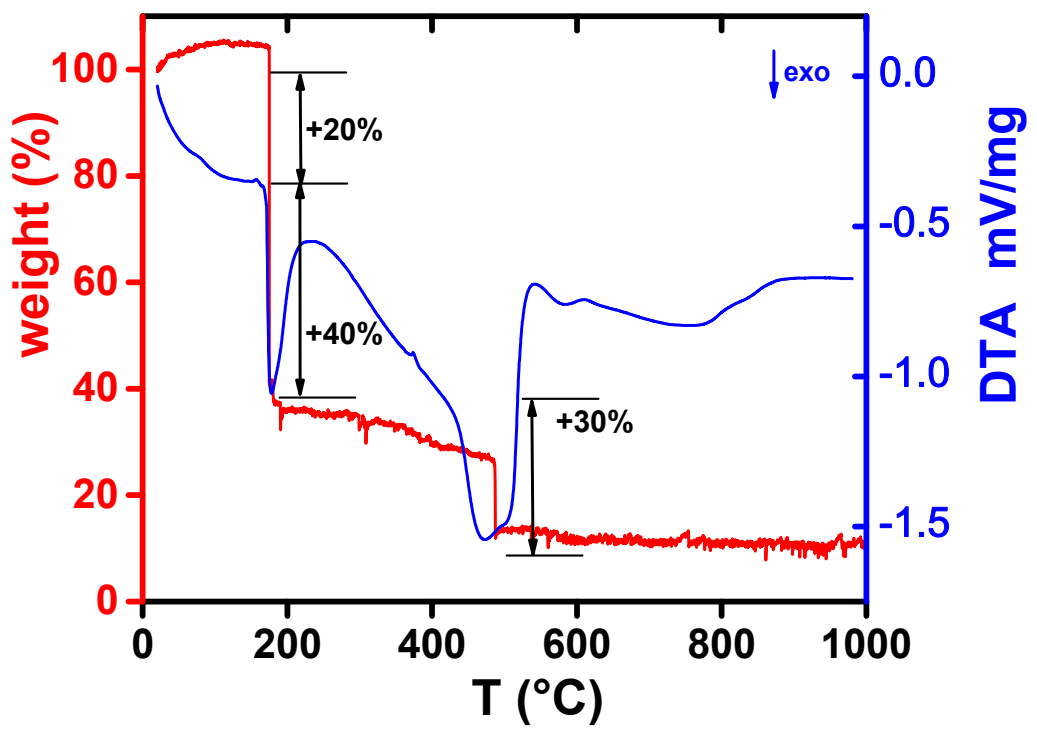

Figure 2. Thermogravimetric and differential thermal analysis curves of BITIVOX gel synthesized by the complex polymerization technique.

Figure 3 shows dilatometric curves of BITIVOX compounds with the following temperature profile: room temperature to $700{ }^{\circ} \mathrm{C}$ or $800{ }^{\circ} \mathrm{C}$ for a $5 \mathrm{~min}$ dwelling and back to room temperature. Figure 3 a refers to with and without the application of $200 \mathrm{~V} \mathrm{~cm}^{-1}$ during $5 \mathrm{~min}$ for a programmed $800{ }^{\circ} \mathrm{C}$ for $30 \mathrm{~min}$. Figure $3 \mathrm{~b}$ with the application of $200 \mathrm{~V} \mathrm{~cm}^{-1}$ during $5 \mathrm{~min}$ when the samples reached $700{ }^{\circ} \mathrm{C}$ or $800{ }^{\circ} \mathrm{C}$.

The application of the electric field for 5 min when the BITIVOX temperature reached $800{ }^{\circ} \mathrm{C}$ Figure 3a) promoted additional 3.2\% shrinkage of the sample thickness (13.6-10.4\%. The difference may be due to the Joule heating caused by the electric current pulse limited to $1 \mathrm{~A}$ through the ceramic pellet. Figure $3 \mathrm{~b}$ shows the difference in densification when the electric field was applied at two temperatures, $700{ }^{\circ} \mathrm{C}$ and $800{ }^{\circ} \mathrm{C}$ : the higher the temperature the higher the shrinkage upon applying the same electric field for the same time and electric current limit. A simple explanation is that increasing the temperature decreases the electrical resistivity of the ceramic pellet $\left[\rho=\rho_{0} \exp (\mathrm{H} / \mathrm{kT}), \rho\right.$ is the resistivity at the absolute temperature $T, \rho_{0}$ the pre-exponential factor, $H$ the activation energy and $\mathrm{k}$ the Boltzmann constant], allowing for an increase in the electric current $\mathrm{J}$ for a constant applied 
voltage. The temperature $\mathrm{T}$ resulting from the application of the electric field $\mathrm{E}$ may be estimated by using the black-body radiation equation $\mathrm{T}=\left[\mathrm{T}_{0}^{4}+\mathrm{W} / \mathrm{A} \sigma\right]^{1 / 4}[41] . \mathrm{T}_{0}$ is the temperature the electric current pulse starts, $\mathrm{A}=1.82 \times 10^{-5} \mathrm{~m}^{2}$ the pellet parallel surface area, $\sigma=5.67 \times 10^{-8} \mathrm{~W} \mathrm{~m}^{-2} \mathrm{~K}^{-4}$ the Stefan-Boltzmann constant, $\mathrm{W}=\mathrm{V} \times \mathrm{J} \times \sqrt{2} / 2\left(\mathrm{~V}=\mathrm{E} \times\right.$ pellet thickness): $2170{ }^{\circ} \mathrm{C}$ is the evaluated temperature when the voltage $\mathrm{V}$ is applied (time $=0 \mathrm{~s}$ in Figure 1 ) and $1090^{\circ} \mathrm{C}$ at $700{ }^{\circ} \mathrm{C}$ and $1120^{\circ} \mathrm{C}$ at $80{ }^{\circ} \mathrm{C}$ at subsequent times, when the power supply voltage drops to keep constant the electric current.

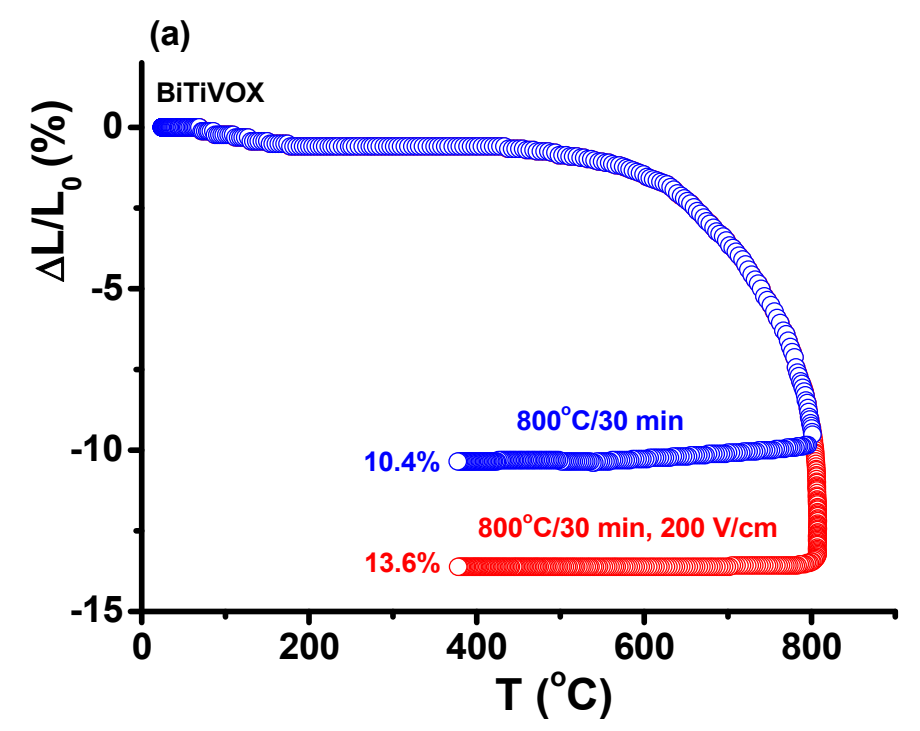

(b)

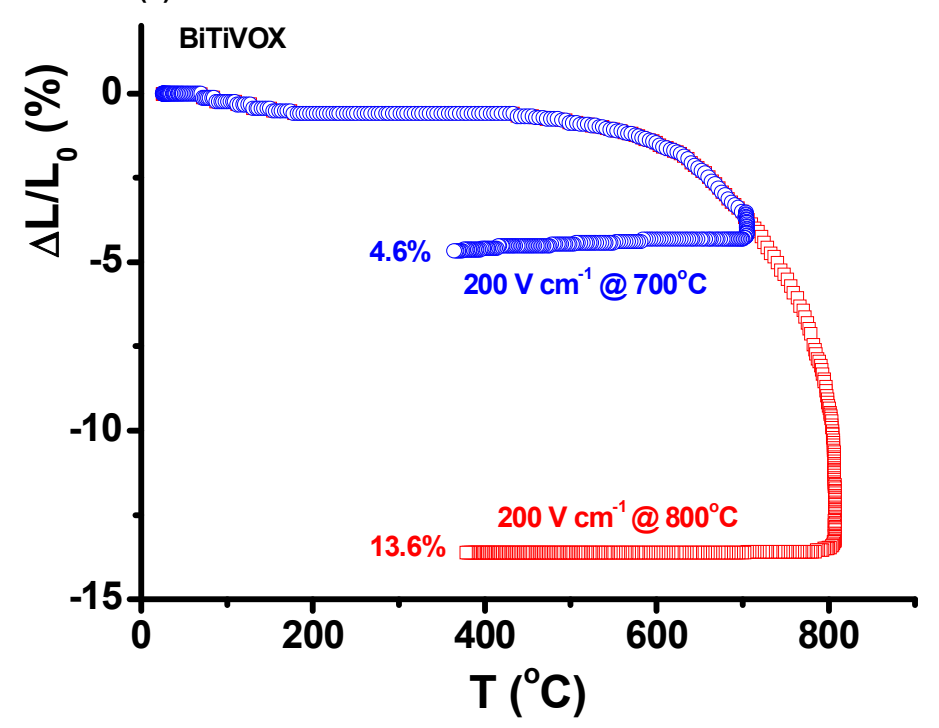

Figure 3. Dilatometric curves of BITIVOX ceramic pellets: (a) heating to $800^{\circ} \mathrm{C} / 30 \mathrm{~min}$ without and with application of $200 \mathrm{~V} \mathrm{~cm}^{-1}$ during $5 \mathrm{~min}$ at $800{ }^{\circ} \mathrm{C}$; (b) applying $200 \mathrm{~V} \mathrm{~cm}^{-1}$ at $700{ }^{\circ} \mathrm{C} / 5 \mathrm{~min}$ and at $800^{\circ} \mathrm{C} / 5 \mathrm{~min}$.

Figure 4 shows the results of the impedance spectroscopy measurements at $400{ }^{\circ} \mathrm{C}$ of the BITIVOX ceramic pellets sintered according to Figure 3 . The BITIVOX sample sintered by applying $200 \mathrm{~V} \mathrm{~cm}^{-1}$ at $800{ }^{\circ} \mathrm{C}$ had bulk electrical resistivity of $0.37 \mathrm{kOhm} . \mathrm{cm}$, while it was $0.76 \mathrm{kOhm} . \mathrm{cm}$ without the application of the electric field (Figure 4a). This means that besides the effect of the furnace temperature heating the sample from its outside surface towards the bulk, Joule heating inside the sample due to electric current pulses helps to improve densification. By decreasing the temperature the electric field is 
applied, there is an increase in the value of the electrical resistivity (Figure $4 \mathrm{~b}$ ). This result has already been reported for other solid electrolytes and the explanation is simple: higher temperature means lower electrical resistivity and higher amplitude of the electric current, with consequent increased Joule heating, promoting therefore higher densification. An extrapolation to $400{ }^{\circ} \mathrm{C}$ of the reported value for the electrical conductivity of the $\mathrm{Bi}_{4} \mathrm{~V}_{1.8} \mathrm{Ti}_{0.2} \mathrm{O}_{11}$ composition sintered at $800{ }^{\circ} \mathrm{C}$ for $12 \mathrm{~h}$ (electrical conductivity at $320^{\circ} \mathrm{C}, \sigma_{320}=2.56 \times 10^{-5} \mathrm{~S} \mathrm{~cm}^{-1}$, activation energy $\mathrm{E}=0.61 \mathrm{eV}$ [32]) leads to $\sigma_{400}=1.1 \times 10^{-4} \mathrm{~S} \mathrm{~cm}^{-1}$, which is 25 times lower than the electrical conductivity of our sample flash sintered at $800{ }^{\circ} \mathrm{C}\left(2.7 \times 10^{-3} \mathrm{~S} \mathrm{~cm}^{-1}\right)$.
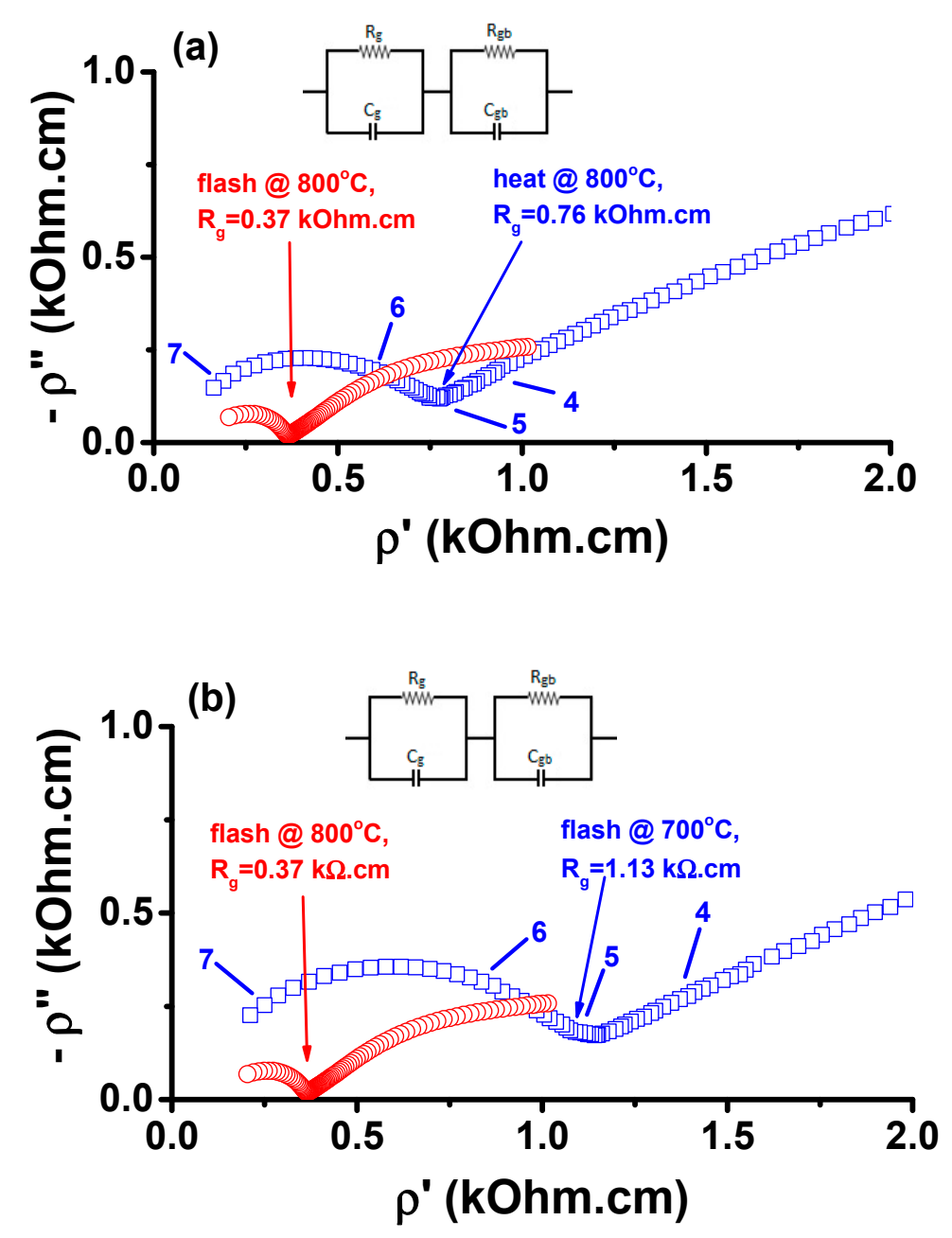

Figure 4. Impedance spectroscopy plots of BITIVOX ceramic pellets and equivalent circuits: (a) sintered at $800^{\circ} \mathrm{C} / 5 \mathrm{~min}$ and flash sintered applying $200 \mathrm{~V} \mathrm{~cm}^{-1}$ at $800^{\circ} \mathrm{C}$ for $5 \mathrm{~min}$; (b) flash sintered applying $200 \mathrm{~V} \mathrm{~cm}^{-1}$ at $700{ }^{\circ} \mathrm{C} / 5 \mathrm{~min}$ and at $800{ }^{\circ} \mathrm{C} / 5 \mathrm{~min}$; Temperature of measurement: $400{ }^{\circ} \mathrm{C}$. Numbers stand for $\log \mathrm{f}(\mathrm{f}: \mathrm{Hz})$.

Figure 5 shows impedance and Bode diagrams of BITIVOX samples flash sintered at $700{ }^{\circ} \mathrm{C}$ and at $800{ }^{\circ} \mathrm{C}$, measured at four temperatures in the $275^{\circ} \mathrm{C}-400{ }^{\circ} \mathrm{C}$ range, for comparison purpose. The diagrams are composed of a skewed semicircle at high frequencies due to the bulk resistivity [42] and a spike at lower frequencies due to electrode polarization [43]. A comparison of the electrical conductivity was possible due to the similar crystallographic phase(s) of all sintered BITIVOX samples (cf. X-ray diffraction results). The sample flash sintered at $800{ }^{\circ} \mathrm{C}$ is a better electric conductor (lower electrical resistivity) than the one flash sintered at $700^{\circ} \mathrm{C}: 4 \mathrm{kOhm} . \mathrm{com}(50), 2$ (20) kOhm.cm, 0.8 (5.8) kOhm.cm and 0.6 (1.9) kOhm.cm for the flash (conventionally) sintered BITIVOX pellets at $275^{\circ} \mathrm{C}$, $300{ }^{\circ} \mathrm{C}, 350{ }^{\circ} \mathrm{C}$ and $400{ }^{\circ} \mathrm{C}$, respectively. 

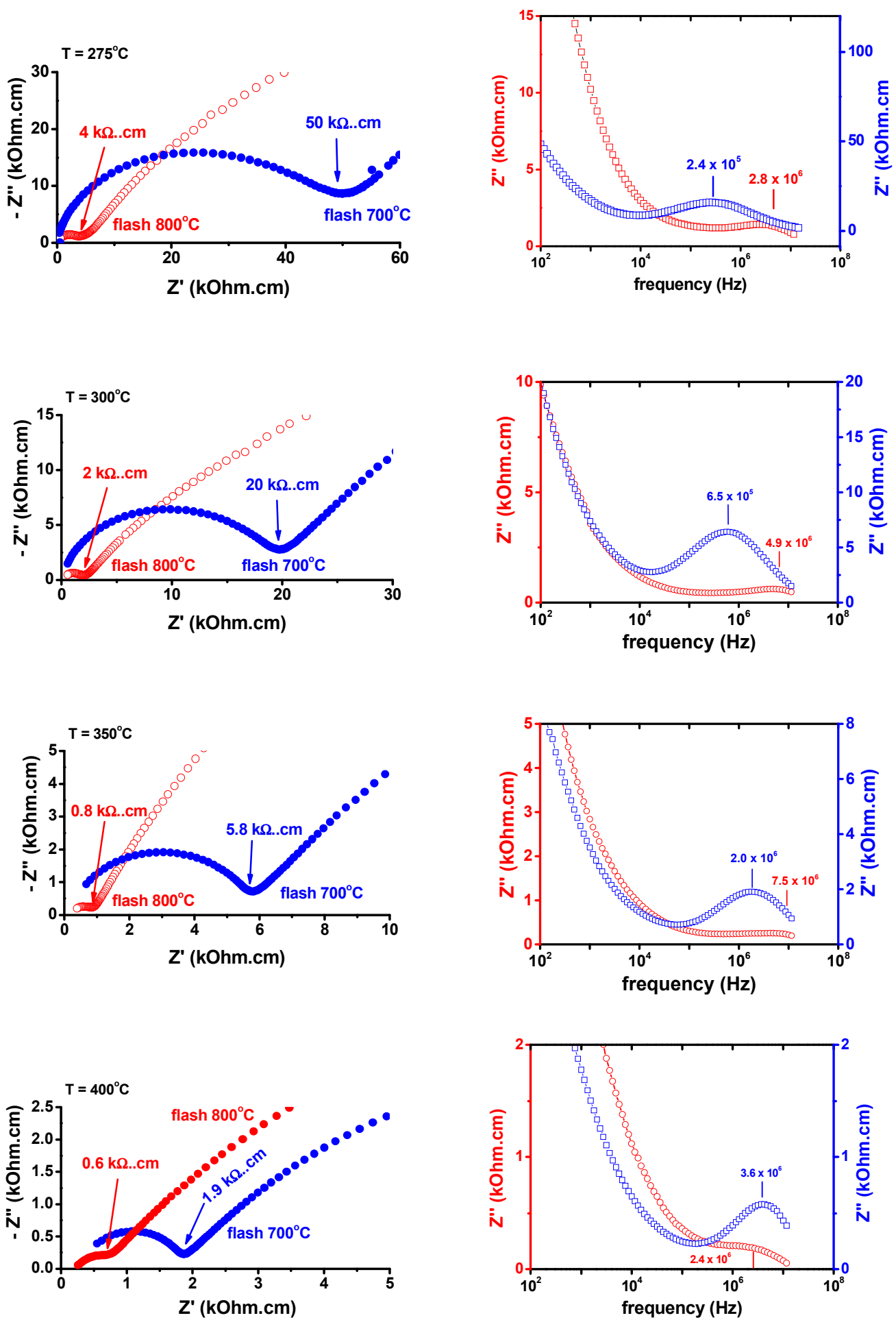

Figure 5. Impedance spectroscopy diagrams (left) and Bode diagrams (right), with data collected at $275{ }^{\circ} \mathrm{C}, 300{ }^{\circ} \mathrm{C}, 350{ }^{\circ} \mathrm{C}$, and $400{ }^{\circ} \mathrm{C}$, of BITIVOX samples flash sintered at $700{ }^{\circ} \mathrm{C} / 5 \mathrm{~min}$ and at $800{ }^{\circ} \mathrm{C} / 5 \mathrm{~min}$. Bulk resistivity values are shown in the left figures. Maximum frequencies in the right figures.

Figure 6 shows the Arrhenius plots of BITIVOX samples sintered at $800{ }^{\circ} \mathrm{C} / 8 \mathrm{~h}$ and flash sintered at $700{ }^{\circ} \mathrm{C}$ and $800{ }^{\circ} \mathrm{C}$. The activation energy for the conductive process was determined as $0.78 \mathrm{eV}$, in agreement with reported values $[17,30]$. A comparison with reported values for the electrical conductivity and the activation energy is shown in Table 1. 


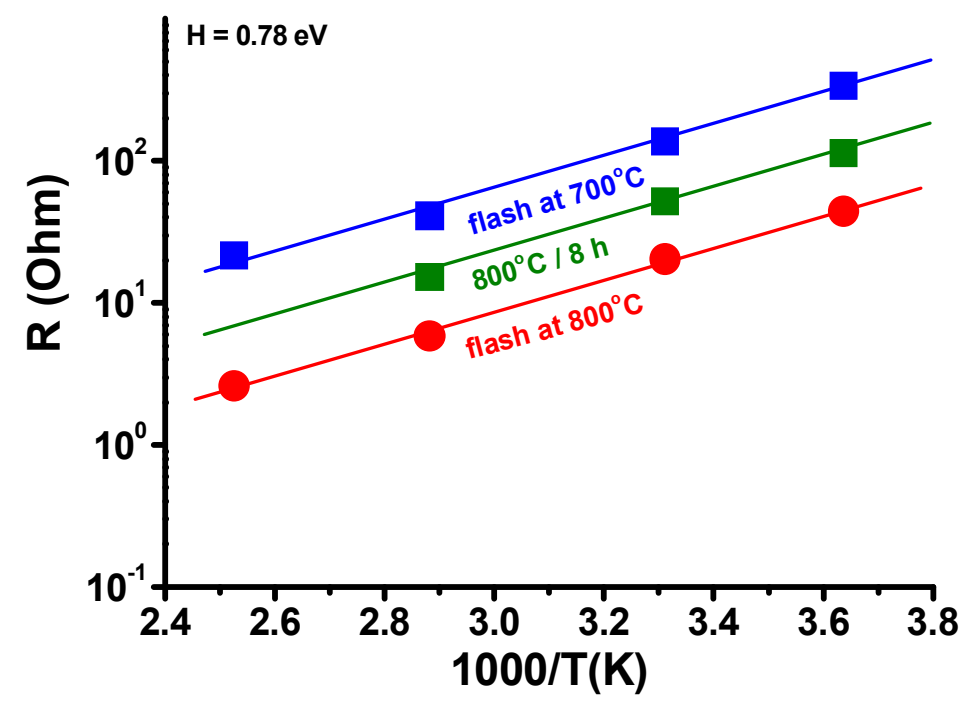

Figure 6. Arrhenius plots of BITIVOX sintered at $800^{\circ} \mathrm{C} / 8 \mathrm{~h}$ and flash sintered at $700{ }^{\circ} \mathrm{C} / 5 \mathrm{~min}$ and $800{ }^{\circ} \mathrm{C} / 5 \mathrm{~min}$.

Table 1. Reported and this work values of electrical conductivity $\sigma$ and activation energy E.

\begin{tabular}{ccccc}
\hline Composition & $\mathbf{T}\left({ }^{\circ} \mathbf{C}\right)$ & $\boldsymbol{\sigma}\left(\mathbf{S ~ c m}^{-\mathbf{1}}\right)$ & $\mathbf{E}(\mathbf{e V})$ & Reference \\
\hline $\mathrm{Bi}_{2} \mathrm{~V}_{0.9} \mathrm{Cu}_{0.1} \mathrm{O}_{9}$ & 227 & $2.9 \times 10^{-4}$ & 0.66 & {$[44]$} \\
$\mathrm{Bi}_{2} \mathrm{~V}_{0.9} \mathrm{Ni}_{0.1} \mathrm{O}_{9}$ & 227 & $3.05 \times 10^{-4}$ & 0.71 & {$[45]$} \\
$\mathrm{Bi}_{2} \mathrm{~V}_{0.9} \mathrm{Zn}_{0.1} \mathrm{O}_{9}$ & 227 & $1.27 \times 10^{-4}$ & 0.73 & {$[45]$} \\
$\mathrm{Bi}_{2} \mathrm{~V}_{0.8} \mathrm{Ti}_{0.2} \mathrm{O}_{9}$ & 320 & $1.1 \times 10^{-4}$ & 0.61 & {$[32]$} \\
$\mathrm{Bi}_{2} \mathrm{~V}_{0.8} \mathrm{Ti}_{0.2} \mathrm{O}_{9}$ & 400 & $3.7 \times 10^{-2}$ & 0.78 & this work \\
\hline
\end{tabular}

Figure 7 shows the scanning electron microscopy images of surfaces of BITIVOX pellets sintered following different procedures: (a) conventionally in air at $800^{\circ} \mathrm{C}$ during $8 \mathrm{~h}$ in a resistive furnace; inside a dilatometer by applying $200 \mathrm{~V} \mathrm{~cm}^{-1}$ at $700{ }^{\circ} \mathrm{C}(\mathrm{b})$ and $800{ }^{\circ} \mathrm{C}$ (c) during $5 \mathrm{~min}$. The FEG-SEM micrographs indicate a broad distribution of irregular grains of average sizes higher than $1 \mu \mathrm{m}$. The sample flash sintered at $800^{\circ} \mathrm{C}$ had larger average grain size than the sample flash sintered at $700^{\circ} \mathrm{C}$, probably due to the lower electrical resistivity, which is exponentially dependent on temperature. The sample flash sintered at $700{ }^{\circ} \mathrm{C}$ for 5 min shows grains similar to those of the sample sintered conventionally for $8 \mathrm{~h}$. This means that the electric current was able to produce Joule heating leading to grain growth similar to the sample heated at $800^{\circ} \mathrm{C} / 8 \mathrm{~h}$. The electric current provides also higher mobility of the charge carriers, increasing local Joule heating, promoting grain growth, decreasing porosity, and consequently improving the total conductivity, as shown in Figure 4a.

Intergranular and intragranular pores were observed in the polished surfaces, evidenced by the large contribution to the bulk electrical resistivity (cf. Figure 4).

After the scanning electron microscopy and electrochemical impedance measurements, the sintered pellets were ground in an agate mortar for using the powders for the X-ray diffraction analyses. The results are shown in Figure 8. All diffraction patterns are similar with minor residuals of the $\mathrm{BiVO}_{4}$ parent phase and were indexed for tetragonal the majority phase (PDF 86-0104) [46]. 


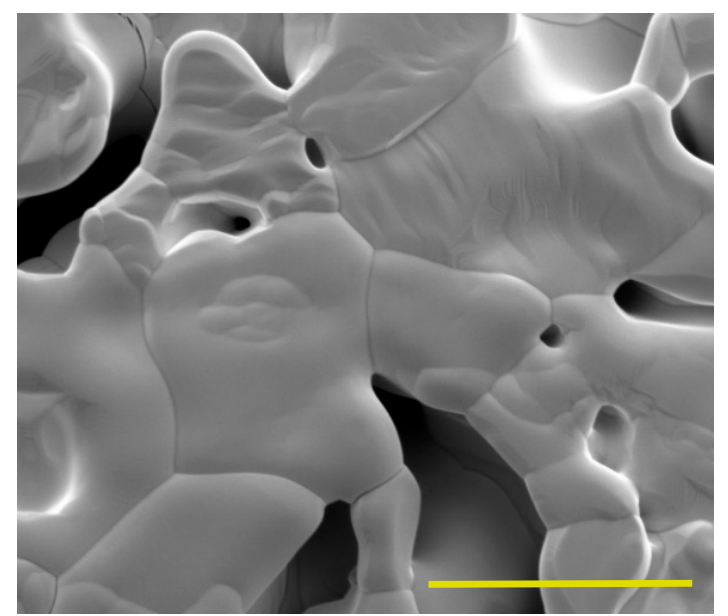

(a) $800{ }^{\circ} \mathrm{C} / 8 \mathrm{~h}$

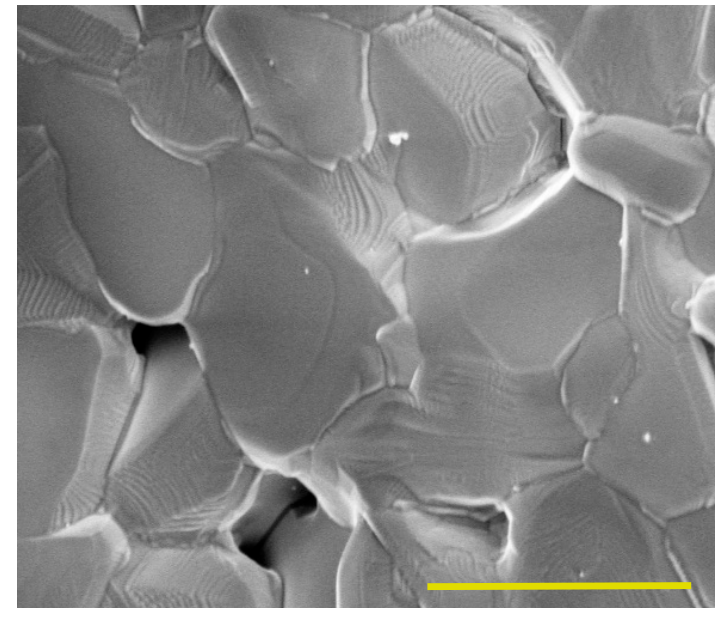

(b) $200 \mathrm{~V} \mathrm{~cm}^{-1}$ at $700{ }^{\circ} \mathrm{C} / 5 \mathrm{~min}$

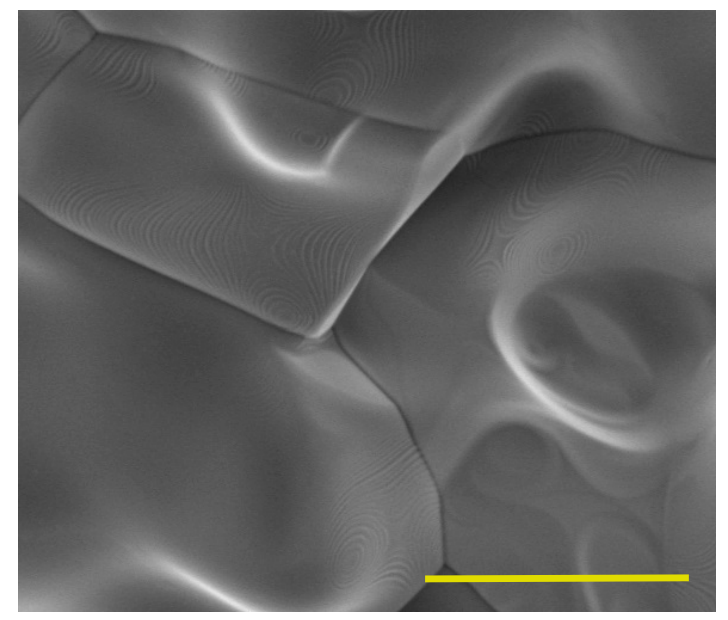

(c) $200 \mathrm{~V} \mathrm{~cm}^{-1}$ at $800{ }^{\circ} \mathrm{C} / 5 \mathrm{~min}$

Figure 7. Scanning electron microscopy images of BITIVOX solid electrolytes (a) sintered at $800{ }^{\circ} \mathrm{C} / 8 \mathrm{~h}$, (b) sintered with $200 \mathrm{~V} \mathrm{~cm}^{-1}$ applied at $700^{\circ} \mathrm{C} / 5 \mathrm{~min}$ and (c) at $800^{\circ} \mathrm{C} / 5 \mathrm{~min}$. Bar length: $5 \mu \mathrm{m}$. 


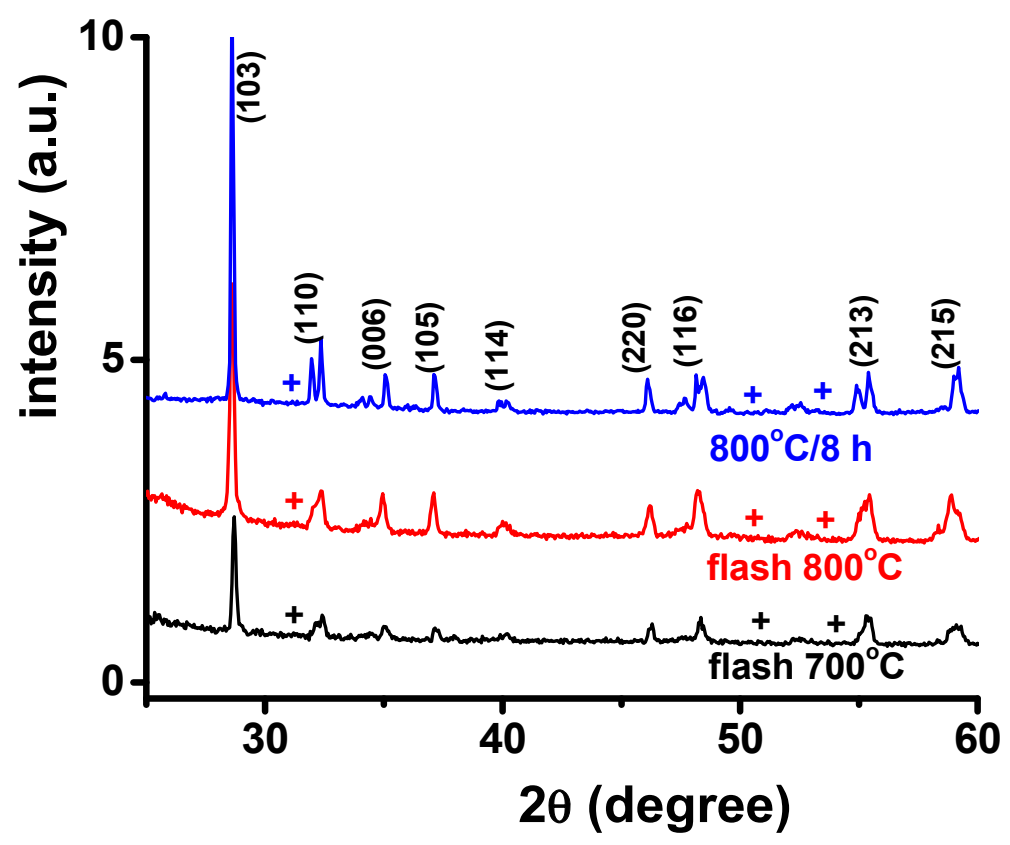

Figure 8. X-ray diffraction patterns of BITIVOX. From top to bottom: sintered at $800{ }^{\circ} \mathrm{C} / 8 \mathrm{~h}$, flash sintered with application of $200 \mathrm{~V} \mathrm{~cm}^{-1}$ at $800{ }^{\circ} \mathrm{C} / 5 \mathrm{~min}$ and at $700{ }^{\circ} \mathrm{C} / 5 \mathrm{~min}$. Also shown the main Miller indices; + location of diffraction peaks of $\mathrm{BiVO}_{4}$.

\section{Conclusions}

$\mathrm{Bi}_{4} \mathrm{~V}_{1.8} \mathrm{Ti}_{0.2} \mathrm{O}_{11}$ (BITIVOX) ceramic powders were successfully synthesized by a complex polymerization method followed by calcination at $750{ }^{\circ} \mathrm{C}$. Compacts of the powders sintered by applying AC electric voltages (flash sintering) at $800^{\circ} \mathrm{C}$ showed enhanced shrinkage and higher electrical conductivity than compacts flash sintered at $700{ }^{\circ} \mathrm{C}$. Moreover, samples flash sintered at $800^{\circ} \mathrm{C}$ for only 5 min achieved larger shrinkage and higher ionic conductivity than samples conventionally sintered by heating at $800^{\circ} \mathrm{C}$ for $8 \mathrm{~h}$. Flash sintering is an effective technique for obtaining BITIVOX solid electrolyte pellets in short times with improved electrical conductivity. Further research work is necessary for achieving higher density samples.

Author Contributions: conceptualization, R.M.; methodology, R.M. and E.N.S.M.; formal analysis, R.M., E.N.S.M. and M.S.M.; investigation, M.S.M., S.G.M.C., R.M. and E.N.S.M.; resources, R.M.; writing-original draft preparation, R.M. and M.S.M.; writing—review and editing, R.M., M.S.M., S.G.M.C. and E.N.S.M.; supervision, R.M.; project administration, R.M.; funding acquisition, R.M. and E.N.S.M.

Funding: This research was funded by the Brazilian Agencies: CNEN, CNPq (Procs. 302357/2018-1 and 305889/2018-4) and FAPESP (CEPID-CDMF Proc. 2013/07296-2).

Acknowledgments: R.M. is grateful to Federal University of ABC for the Senior Visiting Researcher fellowship.

Conflicts of Interest: The authors declare no conflict of interest.

\section{References}

1. Minh, N.Q. Ceramic Fuel Cells. J. Am. Ceram. Soc. 1993, 76, 563-588. [CrossRef]

2. Goodenough, J.B. Oxide-ion electrolytes. Annu. Rev. Mater. Res. 2003, 33, 91-128. [CrossRef]

3. Fergus, J.W. Electrolytes for solid oxide fuel cells. J. Power Sources 2006, 162, 30-40. [CrossRef]

4. Amado, R.S.; Malta, L.G.B.; Garrido, F.M.S.; Medeiros, M.E. Solid oxide fuel cells: Materials, components and configurations. Quim. Nova 2006, 30, 189-197. [CrossRef]

5. Jacobson, A.J. Materials for solid oxide fuel cells. Chem. Mater. 2010, 22, 660-674. [CrossRef]

6. Jagannathan, K.P.; Tiku, S.K.; Ray, H.S.; Ghosh, A.; Subbarao, E.C. Technological applications of solid electrolytes. In Solid Electrolytes and their Application; Subbarao, E.C., Ed.; Plenum Press: New York, NY, USA, 2012; pp. 201-260. 
7. Steele, B.C.H.; Heinzel, A. Materials for fuel cells technology. Nature 2001, 414, 345-352. [CrossRef]

8. Overs, A.; Riess, I. Properties of the solid electrolyte gadolinia-doped ceria prepared by thermal decomposition of mixed cerium-gadolinium oxalate. J. Am. Ceram. Soc. 1982, 65, 606-609. [CrossRef]

9. Abraham, F.; Boivin, J.C.; Mairesse, G.; Nowogrocki, G. The BIMEVOX series a new family of high performances oxide ion conductors. Solid State Ion. 1990, 40, 934-937. [CrossRef]

10. Eguchi, K.; Setogushi, T.; Inoue, T.; Arai, H. Electrical properties of ceria-based oxides and their application to solid oxide fuel cells. Solid State Ion. 1992, 52, 165-172. [CrossRef]

11. Huang, P.N.; Petric, A. Superior oxygen ion conductivity of lanthanum gallate doped with strontium and magnesium. J. Electrochem. Soc. 1996, 143, 1644-1648. [CrossRef]

12. Lacorre, P.; Goutenoire, F.; Bohnke, O.; Retoux, R.; Laligant, Y. Designing fast oxide-ion conductors based on $\mathrm{La}_{2} \mathrm{Mo}_{2} \mathrm{O}_{9}$. Nature 2000, 404, 856-858. [CrossRef] [PubMed]

13. Krok, F.; Abrahams, I.; Bangobango, D.G.; Bogusz, W.; Nelstrop, J.A.G. Electrical and structural study of BICOVOX. Solid State Ion. 1996, 86, 261-266. [CrossRef]

14. Anne, M.; Bachmann, M.; Pernot, M.; Abraaham, F.; Mairesse, G.; Strobel, P. Structure of new anionic conductors $\mathrm{Bi}_{4} \mathrm{~V}_{2(1-x)} \mathrm{M}_{2 x} \mathrm{O}_{11-3 x}, \mathrm{M}=\mathrm{Cu}$, Ni. Physica B 1992, 180, 621-623. [CrossRef]

15. Sharma, V.; Shukla, A.K.; Gopalakrishnan, J. Effect of aliovalent-cation substitution on the oxygen-ion conductivity of $\mathrm{Bi}_{4} \mathrm{~V}_{2} \mathrm{O}_{11}$. Solid State Ion. 1992, 58, 359-362. [CrossRef]

16. Pernot, E.; Anne, M.; Bachmann, M.; Strobel, P.; Fouletier, J.; Vannier, R.N.; Mairesse, G.; Abraham, F.; Nowogrocki, G. Structure and conductivity of $\mathrm{Cu}$ - and Ni-substituted $\mathrm{Bi}_{4} \mathrm{~V}_{2} \mathrm{O}_{5}$ compounds. Solid State Ion. 1994, 70, 259-263. [CrossRef]

17. Krok, F.; Abrahams, I.; Malys, M.; Bogusz, W.; Nelstrop, J.A.G. Structural and electrical characterisation of BICOCUVOX. Ionics 1997, 3, 235-238. [CrossRef]

18. Sammers, N.M.; Tompsett, G.A.; Nafe, H.; Aldinger, F. Bismuth based oxide electrolytes structure and ionic conductivity. J. Eur. Ceram. Soc. 1999, 19, 1801-1826. [CrossRef]

19. Abrahams, I.; Krok, F.; Malys, M.; Bush, A.J. Defect structure and ionic conductivity as a function of thermal history in BIMGVOX solid electrolytes. J. Mater. Sci. 2001, 36, 1099-1104. [CrossRef]

20. Guillodo, M.; Fouletier, J.; Dessemond, L.; Gallo, P.D. Electrical properties of dense Me-doped bismuth vanadate $(\mathrm{Me}=\mathrm{Cu}, \mathrm{Co}) \mathrm{p}_{\mathrm{O} 2}$-dependent conductivity determined by impedance spectroscopy. J. Eur. Ceram. Soc. 2001, 21, 2331-2344. [CrossRef]

21. Godinho, M.J.; Bueno, P.R.; Orlandi, M.O.; Leite, E.R.; Longo, E. Ionic conductivity of $\mathrm{Bi}_{4} \mathrm{Ti}_{0.2} \mathrm{~V}_{1.8} \mathrm{O}_{10.7}$ polycrystalline ceramics obtained by the polymeric precursor route. Mater. Lett. 2003, 57, 2540-2544. [CrossRef]

22. Abrahams, I.; Krok, F. A model for the mechanism of low temperature ionic conduction in divalent-substituted $\gamma$-BIMEVOXes. Solid State Ion. 2003, 157, 139-145. [CrossRef]

23. Paydar, M.H.; Hadian, A.M.; Fafilek, G. Ionic conductivity and crystal structure relationships in Ti/Cu substituted $\mathrm{BI}_{4} \mathrm{~V}_{2} \mathrm{O}_{11}$. J. Mater. Sci. 2004, 39, 1357-1361. [CrossRef]

24. Cho, H.S.; Sakai, G.; Shimanoe, K.; Yamazoe, N. Preparation of BiMeVOx $(\mathrm{Me}=\mathrm{Cu}, \mathrm{Ti}, \mathrm{Zr}, \mathrm{Nb}, \mathrm{Ta})$ compounds as solid electrolyte and behavior of their oxygen concentration cells. Sens. Actuators B 2005, 109, 307-314. [CrossRef]

25. Chmielowiec, J.; Pasciak, G.; Bujlo, P. Ionic conductivity and thermodynamic stability of La-doped BIMEVOX. J. Alloys Compd. 2008, 451, 676-678. [CrossRef]

26. Beg, S.; Salami, N.S. Study on the electrical properties of Co-Ti double substituted $\mathrm{Bi}_{4} \mathrm{~V}_{2} \mathrm{O}_{11}$. J. Alloys Compd. 2014, 586, 302-307. [CrossRef]

27. Beg, S.; Al-Areqi, N.A.S.; Al-Alas, A.; Hafeez, S. Co(III)-NI (II) double substituted bismuth vanadate: Synthesis, phase stabilization, and structural and electrical characterization. Ionics 2014, 20, 269-274. [CrossRef]

28. Fuierer, P.; Maier, M.; Exner, J.; Moos, R. Anisotropy and thermal stability of hot-forged BICUTIVOX oxygen ion conducting ceramics. J. Eur. Ceram. Soc. 2014, 34, 943-951. [CrossRef]

29. Roy, V.; Sahu, S.; Avasthi, A.; Bharadwaj, S. Synthesis, electrical and thermal properties of $\mathrm{Bi}_{4} \mathrm{~V}_{2-\mathrm{x}} \mathrm{Me}_{\mathrm{x}} \mathrm{O}_{11}$ $(\mathrm{Me}=\mathrm{Nb}, \mathrm{Zr}$. Y and $\mathrm{Cu}$ with $\mathrm{x}=0.0$ and 0.06) ceramics. J. Therm. Anal. Calorim. 2014, 115, 1265-1271. [CrossRef]

30. Beg, S.; Haneef, S. Study on phase stability and ionic conductivity in TiIV-substituted bismuth vanadate. Phase Transit. 2014, 87, 821-831. [CrossRef] 
31. Piva, R.H.; Biz, H.; Piva, D.H.; Morelli, M.R. Facile preparation of BIMEVOX powders via melting process: From synthesis to sintering optimization. Ceram. Int. 2016, 42, 7088-7098. [CrossRef]

32. Singh, V.; Gosh, S.; Aich, S.; Roy, B. Low temperature solid oxide electrolytes (LT-SOE): A review. J. Power Sources 2017, 339, 103-135. [CrossRef]

33. Yang, D.; Conrad, H. Enhanced sintering rate of zirconia (3Y-TZP) by application of a small AC electric field. Scr. Mater. 2010, 63, 328-331. [CrossRef]

34. Muccillo, R.; Kleitz, M.; Muccillo, E.N.S. Flash grain welding in yttria stabilized zirconia. J. Eur. Ceram. Soc. 2011, 31, 1517-1521. [CrossRef]

35. Grasso, S.; Sakka, Y.; Rendtorff, N.; Hu, C.; Maizza, G.; Borodianska, H.; Vasylkiv, O. Modeling of the temperature distribution of flash sintered zirconia. J. Ceram. Soc. Japan 2011, 119, 144-146. [CrossRef]

36. Raj, R. Joule heating during flash sintering. J. Eur. Ceram. Soc. 2012, 32, 2293-2301. [CrossRef]

37. Dancer, C.E.J. Flash sintering of ceramic materials. Res. Express 2016, 3, 102001. [CrossRef]

38. Yu, M.; Grasso, S.; McKinnon, R.; Saunders, T.; Reece, M.J. Review of flash sintering: Materials, mechanisms and modelling. Adv. Appl. Ceram. 2016, 116, 24-60. [CrossRef]

39. Muccillo, R.; Muccillo, E.N.S. An experimental setup for shrinkage evaluation during electric field-assisted flash sintering: Application to yttria-stabilized zirconia. J. Eur. Ceram. Soc. 2013, 33, 515-520. [CrossRef]

40. Kleitz, M.; Kennedy, J.H. Resolution of multicomponent impedance diagrams. In Fast Ion Transport in Solids; Mundy, J.N., Shenoy, G.K., Vashishta, P., Eds.; Elsevier North Holland, Inc.: New York, NY, USA, 1979; pp. 185-188. ISBN 0444003533.

41. Muccillo, E.N.S.; Muccillo, R. Electric field-assisted sintering of tin dioxide with manganese dioxide addition. J. Eur. Ceram. Soc. 2014, 34, 3699-3706. [CrossRef]

42. Fletcher, J.G.; West, A.R.; Irvine, J.T.S. The AC-impedance response of the physical interface between yttria-stabilized zirconia and $\mathrm{YBa}_{2} \mathrm{Cu}_{3} \mathrm{O}_{7-\mathrm{x}}$. J. Electrochem. Soc. 1995, 142, 2650-2654. [CrossRef]

43. Barsoukov, E.; Macdonald, J.R. Impedance Spectroscopy: Theory, Experiment, and Applications, 2nd ed.; John Wiley and Sons, Inc.: Hoboken, NJ, USA, 2005; ISBN 978-0471647492.

44. Dygas, J.R.; Krok, F.; Bogusz, P.; Kurek, P.; Reiselhuber, K.; Breiter, M.W. Impedance study of BICUVOX ceramics. Solid State Ion. 1994, 70-71, 239-247. [CrossRef]

45. Kurek, P.; Breiter, M.W. Thermal stability and ionic conductivity of the BIMEVOX.10 ceramics $(\mathrm{ME}=\mathrm{Zn}, \mathrm{Ni})$. Solid State Ion. 1996, 86-88, 131-135. [CrossRef]

46. Tripathy, D.; Pandey, A. Structural and impedance studies of TiIV and NbV co-doped bismuth vanadate system. J. Alloys Compd. 2018, 737, 136-143. [CrossRef] 